\title{
PEMANFAATAN KITOSAN DARI CANGKANG BEKICOT (Achatina fulica) SEBAGAI PENGAWET IKAN KEMBUNG (Rastrelliger sp) DAN IKAN LELE (Clarias batrachus)
}

\author{
Sari Wahyu Waryani, Rika Silvia, Farida Hanum \\ Departemen Teknik Kimia, Fakultas Teknik, Universitas Sumatera Utara \\ Jalan Almamater, Medan, 20155, Indonesia \\ Email: sari_wahyu92@yahoo.com
}

\begin{abstract}
Abstrak
Upaya yang harus dilakukan untuk menjaga kualitas ikan dengan menggunakan senyawa antimikroba salah satunya adalah kitosan. Pada penelitian ini, karakterisasi kitosan dari cangkang bekicot (Achatina fulica) memiliki kadar air 5,07\%, kadar abu 1,8\% dan derajat deasetilasi (DD) 75,13\%. Penggunaan kitosan dalam penelitian ini adalah untuk mengetahui kondisi yang optimal pada konsentrasi kitosan dan waktu penyimpanan ikan kembung (Rastrelliger sp) dan ikan lele (Clarias batrachus) dari aspek mikrobiologi dan organoleptik. Penelitian ini menggunakan variasi konsentrasi kitosan adalah 1\%, 1,5\%, 2\% dan 2,5\% dilarutkan dalam $1 \%$ asam asetat. Pengamatan dilakukan dengan variasi waktu penyimpanan $10 \mathrm{jam}, 15$ jam, 20 jam dan 25 jam dan pemberian larutan kitosan dengan cara perendaman dan penyemprotan dengan parameter pengamatan Total Volatile Base (TVB), organoleptik dan pH ikan. Berdasarkan hasil analisa, hasilnya menunjukkan bahwa konsentrasi kitosan maksimum pada ikan kembung (Rastrelliger $s p$ ) dan ikan lele adalah $1,5 \%$ (Clarias batrachus) dan perlakuan dengan cara perendaman merupakan perlakuan yang terbaik. Penggunaan larutan kitosan pada ikan kembung (Rastrelliger sp) bertahan 20 jam sedangkan ikan lele (Clarias batrachus) bertahan 15 jam..
\end{abstract}

Kata kunci : Total Volatile Base, organoleptik, pH, ikan kembung, ikan lele

\begin{abstract}
The efforts that should be made to maintain the quality of fish is by using antimicrobial compounds, one of which is chitosan. In this research, characterization of chitosan from shell snail (Achatina fulica) has a water content of $5.07 \%$, ash content of $1.8 \%$ and the degree of deacetylation (DD) $75.13 \%$. The use of chitosan in this study was to determine the optimal conditions on chitosan concentration and storage time of mackerel (Rastrelliger sp) and catfish (Clarias batrachus) from the microbiological and organoleptic aspects. This research used a variation of the concentration of chitosan was 1\%, 1.5\%, 2\% and $2.5 \%$ dissolved in $1 \%$ acetic acid. Observations were do with variation the storage time 10 hours, 15 hours, 20 hours and 25 hours and the provision of chitosan solution by soaking and spraying with the observation parameters Total Volatile Base (TVB), organoleptic and $\mathrm{pH}$ of fish. Based on the analysis, the results showed that the maximum concentration of chitosan on mackerel (Rastrelliger sp) and catfish (Clarias batrachus) is 1,5\% and treatment by means of immersion is the best treatment. The use of chitosan solution on mackerel (Rastrelliger sp) survived 20 hours while catfish (Clarias batrachus) survived 15 hours.
\end{abstract}

Keywords :Total Volatile Base, organoleptic, pH, mackerel, catfish

\section{PENDAHULUAN}

Ikan merupakan produk pangan yang sangat mudah rusak. Pembusukan ikan terjadi setelah ikan ditangkap atau mati. Pada kondisi suhu tropik, ikan membusuk dalam waktu 12-20 jam tergantung spesies, alat atau cara penangkapan. Pendinginan akan memperpanjang masa simpan ikan. Pada suhu $15-20^{\circ} \mathrm{C}$, ikan dapat disimpan hingga sekitar 2 hari, pada suhu $5^{\circ} \mathrm{C}$ tahan selama 5-6 hari, sedangkan pada suhu $0^{\circ} \mathrm{C}$ dapat mencapai $9-14$ hari, tergantung spesies ikan [9].

Penggunaan formalin sebagai pengawet bahan pangan diduga karena tingkat kesadaran produsennya akan kesehatan masyarakat masih sangat rendah, disamping mereka tidak mempunyai pengetahuan yang memadai mengenai bahaya bahan kimia terlarang tersebut. Formalin sangat mudah dijumpai di pasar bebas dengan harga yang murah. Baik formalin maupun boraks merupakan bahan kimia yang sangat berbahaya bagi kesehatan manusia [2]. Salah satu alternatif pengganti formalin sebagai pengawet makanan adalah penggunaan kitosan yang lebih aman dan tidak berefek negatif terhadap kesehatan tubuh. Kitosan dapat berfungsi sebagai bahan pengawet karena mempunyai sifat anti bakteri [15;23].

Sesuai SK Menkes RI No. 722 th 1988 tentang Bahan Tambahan Makanan, yang dimaksud bahan pengawet adalah bahan tambahan makanan yang mencegah atau menghambat fermentasi pengasaman atau peruraian lain terhadap makanan yang disebabkan oleh mikroorganisme. Menurut Food and Drugs Administration (FDA), keamanan suatu pengawet makanan harus mempertimbangkan jumlah yang mungkin dikonsumsi dalam produk makanan atau jumlah zat yang akan terbentuk dalam makanan dari penggunaan pengawet [18]. Tujuan penelitian ini adalah untuk mengetahui 
kitosan sebagai alternatif pengawet alami, mengetahui kondisi yang optimal pada konsentrasi kitosan dan waktu penyimpana, dan mengetahui bagaimana cara pemberian larutan kitosan terbaik untuk memperpanjang masa simpan ikan.

Cangkang bekicot (Achatina fullica) mengandung zat kitin sekitar 70\% - 80\% sedangkan dalam udang terdapat kitin sebanyak $15 \%$ - $20 \%$ dan rajungan $20 \%$ - 30\% [20]. Penelitian kitosan dari cangkang bekicot pernah dilakukan oleh Kusumaningsih et al [22] diperoleh kadar air 3,265\% dan derajat deasetilasi 74,78-77,99\%.

\section{BAHAN DAN METODE Prosedur Penelitian \\ Pembuatan Kitosan}

Sintesis kitosan dari cangkang bekicot dilakukan melalui proses deproteinasi, demineralisasi dan deasetilasi. Kitin diisolasi dari cangkang bekicot yang diperoleh dari sawah-sawah dengan proses deproteinasi dalam larutan $\mathrm{NaOH}$ 3,5\% dengan perbandingan $1: 10(\mathrm{~g} / \mathrm{ml})$. Campuran diaduk konstan menggunakan magnetic stirer di atas hot plate pada suhu $65^{\circ} \mathrm{C}$ selama 2 jam. Selanjutnya proses demineralisasi dengan $\mathrm{HCl} 1 \mathrm{~N}$ dengan perbandingan 1:15 (g/ml), pengadukan dilakukan terus-menerus selama 30 menit dengan suhu $40^{\circ} \mathrm{C}$. Hasil proses demineralisasi yaitu kitin dimasukkan ke dalam larutan $\mathrm{NaOH} 60 \%$ dengan perbandingan 1:20 (g/ml) dan diaduk sambil dipanaskan di atas hot plate pada suhu $100-140^{\circ} \mathrm{C}$ selama 1 jam, dan proses ini menghasilkan produk yang disebut kitosan [22].

\section{Pemanfaatan Kitosan Sebagai Pengawet Ikan}

Untuk mencari optimalisasi kitosan sebagai bahan pengawet ikan dengan cara melarutkan kitosan (w/v) kedalam asam asetat 1\% (v/v). Sampel ikan masing-masing direndam atau disemprot dalam larutan kitosan dengan konsentrasi yang bervariasi dengan perbandingan 1 $\mathrm{kg}$ ikan/1 L larutan kitosan, lalu didiamkan pada suhu ruangan [9].

\section{Parameter Pengamatan}

Pengujian organoleptik ditujukan pada mata, insang, lendir permukaan tubuh, daging, bau dan tekstur. Metode yang digunakan untuk uji organoleptik adalah metode score sheet dengan skala nilai 1-9. Nilai organoleptik 9 menunjukkan ikan dalam kondisi sangat segar. Kondisi ikan segar ditunjukkan dengan nilai 7-8. Nilai 5-6 merupakan ambang batas antara kondisi ikan baik dan jelek. Ikan dinyatakan busuk dan tidak layak dikonsumsi yaitu pada nilai organoleptik 1-4 [11].

Pengukuran $\mathrm{pH}$ dilakukan dengan menggunakan $\mathrm{pH}$ meter universal. Pengukuran dilakukan dengan cara meletakkan kertas $\mathrm{pH}$ pada permukaan daging ikan, kemudian perubahan warna pada kertas $\mathrm{pH}$ disesuaikan dengan warna indikator $\mathrm{pH}$.

Uji TVB-N dilakukan berdasarkan SNI-014495-1998.Sampel ikan kembung yang telah dihaluskan ditimbang sebanyak $2 \mathrm{~g}$. Kemudian sampel dimasukkan ke dalam blender dan ditambah $75 \mathrm{ml}$ larutan TCA 7\% dan dihaluskan kembali selama 1 menit. Selanjutnya sampel disaring dan diuji kadar TVB-Nnya. $1 \mathrm{ml}$ asam borat dimasukkan ke dalam inner chamber cawan conway, kemudian filtrat sampel dimasukkan ke bagian luar cawan conway. Selanjutnya, cawan conway ditutup, lalu ditambahkan $1 \mathrm{ml}$ larutan $\mathrm{K}_{2} \mathrm{CO}_{3}$ pada bagian luar. Bagi blanko, filtrat diganti dengan larutan TCA 5\%. Inkubasi sampel pada suhu $35^{\circ} \mathrm{C}$ selama 2 jam. Setelah diinkubasi bagian dalam cawan conway, baik pada blanko maupun sampel, dititrasi dengan $\mathrm{HCl} 0,02 \mathrm{~N}$ sampai berwarna merah muda seperti pada blanko [4].

[4] $\mathrm{TVB}=\left(\mathrm{V}_{\text {sampel }^{-}} \mathrm{V}_{\text {blanko }}\right) \times \mathrm{N} \mathrm{HCl} \times 14,007 \times 100$ Berat sampel

\section{HASIL DAN PEMBAHASAN}

Berikut perbandingan parameter standar mutu kitosan dengan hasil penelitian.

Tabel 1. Perbandingan Parameter Standar Mutu Kitosan dengan Hasil Penelitian

\begin{tabular}{|l|c|c|}
\hline Parameter & $\begin{array}{c}\text { Standar Mutu } \\
\text { Kitosan[21] }\end{array}$ & $\begin{array}{c}\text { Hasil } \\
\text { Penelitian }\end{array}$ \\
\hline $\begin{array}{l}\text { Ukuran } \\
\text { partikel }\end{array}$ & $\begin{array}{c}\text { Serpihan } \\
\text { sampai serbuk }\end{array}$ & Serbuk \\
\hline Kadar air & $\leq 10 \%$ & $5,07 \%$ \\
\hline Kadar abu & $\leq 2 \%$ & $1,8 \%$ \\
\hline $\begin{array}{l}\text { Warna } \\
\text { Larutan }\end{array}$ & Jernih & Jernih \\
\hline $\begin{array}{l}\text { Derajat } \\
\text { deasetilasi }\end{array}$ & $\geq 70 \%$ & $75,13 \%$ \\
\hline
\end{tabular}

Bentuk kitosan sangat dipengaruhi oleh bahan baku kitosan yang digunakan. Bentuk partikel akan mempengaruhi kelarutan kitosan dimana bentuk serbuk akan mudah larut dalam pelarut [3].

Kadar air kitosan $(5,07 \%)$ yang dihasilkan telah memenuhi standar kitosan komersil $(\leq 10 \%)$, sedangkan kadar air yang diperoleh oleh Kusumaningsih [22] adalah (3,265\%).

Semakin besar derajat deasetilasi kitosan maka semakin sedikit gugus asetilnya, dan berakibat semakin kecil berat molekulnya [1]. Tabel 1 menunjukkan derajat deasetilasi kitosan sebesar $75,13 \%$ dan telah memenuhi standar mutu kitosan ( $\geq 70 \%$ ) sedangkan derajat deasetilasi (DD) yang diperoleh oleh Kusumaningsih [22] adalah (74,7877,99\%).

Analisa FT-IR dilaksanakan untuk memperoleh nilai derajat deasetilasi (DD).

$\% \mathrm{~N}$ - deasetilasi $=\left[1-\frac{A 1655 \times 1}{A 3450 \times 1,33}\right] \times 100 \%[17]$ 
Berikut gambar hasil analisa FT-IR kitosan dari cangkang bekicot.

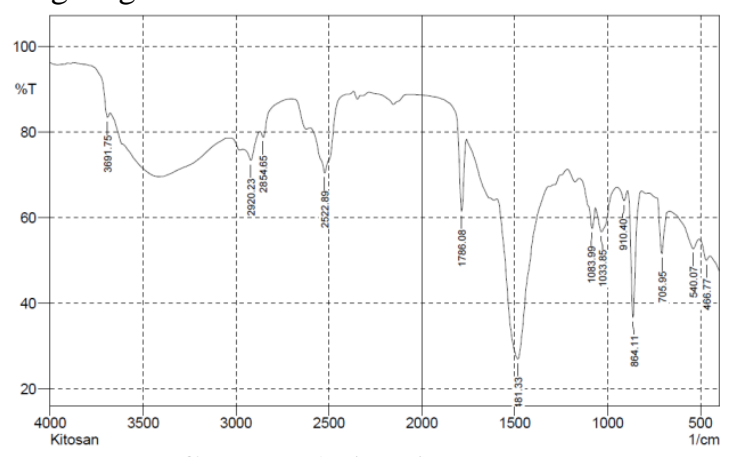

Gambar 1. Analisa FT-IR

Berdasarkan hasil analisis karakteristik kitosan yang diperoleh pada tabel 1 menunjukkan bahwa kitosan yang dihasilkan telah memenuhi standar mutu kitosan sehingga dapat digunakan pada proses selanjutnya.

\section{Analisa TVB (Total Volatile Base)}

Berikut akan dijelaskan hasil analisa TVB (Total Volatile Base) pada ikan kembung (Rastrelliger $s p$ ) dan ikan lele (Clarias batrachus) sebagai berikut.

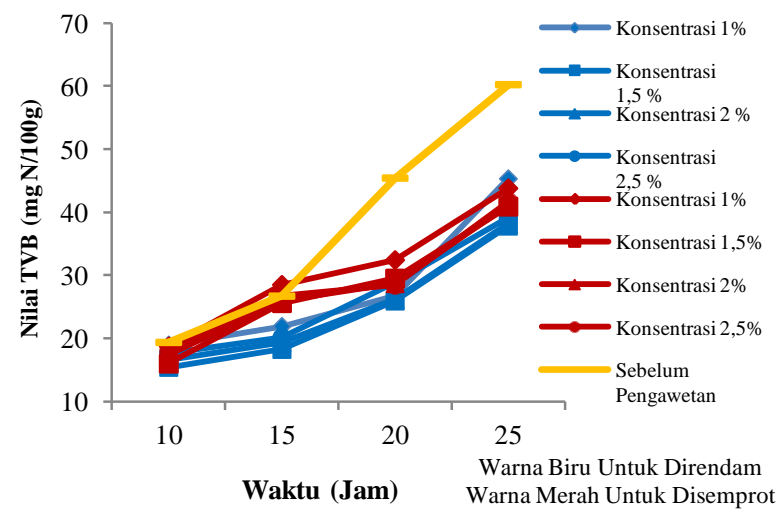

Gambar 2.a Perubahan Nilai TVB pada ikan kembung (Rastrelliger sp)

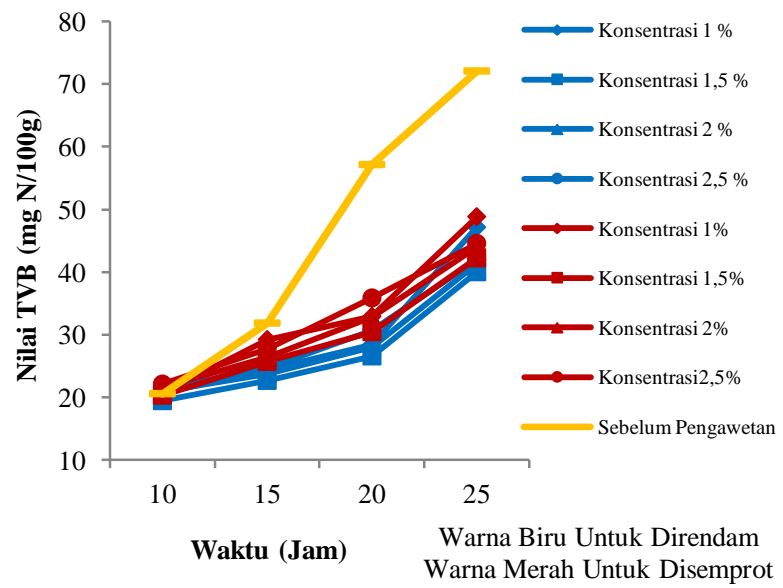

Gambar 2.b Perubahan Nilai TVB pada ikan lele (Clarias batrachus)
Tabel 2. Standar Mutu Kesegaran Ikan [7]

\begin{tabular}{|l|c|}
\hline \multicolumn{1}{|c|}{ Mutu Ikan } & $\begin{array}{c}\text { Nilai TVB (mg N/100 g } \\
\text { daging ikan) }\end{array}$ \\
\hline Sangat segar & $<10$ \\
\hline Segar & $10-20$ \\
\hline $\begin{array}{l}\text { Batas dapat } \\
\text { dimakan }\end{array}$ & $20-30$ \\
\hline Busuk & $>30$ \\
\hline
\end{tabular}

Uji Total Volatile Base adalah salah satu metode pengukuran untuk menentukan kesegaran ikan yang didasarkan pada akumulasi senyawasenyawa basa seperti amoniak, trimetialamin, dan senyawa volatile lainnya yang menguap [5].

Pada gambar 2.a menunjukkan bahwa ikan Kembung (Rastrelliger $s p$ ) dengan perlakuan direndam hasil maksimum yaitu konsentrasi 1,5\% batas ikan layak dikonsumsi pada jam ke-20 dengan nilai TVB 25,94 mg N/100 g, sedangkan hasil minimum yaitu konsentrasi $2,5 \%$ batas ikan layak dikonsumsi pada jam ke-20 dengan nilai TVB 28,83 mg N/100 g. Ikan kembung (Rastrelliger $s p$ ) dengan perlakuan disemprot hasil maksimum yaitu konsentrasi $2,5 \%$ batas ikan layak dikonsumsi pada jam ke-20 dengan nilai TVB 28,43 mg N/100 g, sedangkan hasil minimum yaitu konsentrasi $1 \%$ batas ikan layak dikonsumsi pada jam ke-20 dengan nilai TVB 32,43 mgN/100 g. Sedangkan pada keadaan normal (sebelum pengawetan) ikan mulai membusuk pada jam ke-20 dengan nilai TVB 45,43 mgN/100 g. Dari uraian diatas dapat dilihat bahwa data hasil penelitian dengan perlakuan memiliki nilai TVB yang rendah dibandingkan dengan keadaan normal (sebelum pengawetan).

Pada gambar 2.b menunjukkan bahwa ikan Lele (Clarias batrachus) dengan perlakuan direndam hasil maksimum yaitu konsentrasi $1,5 \%$ batas ikan layak dikonsumsi pada jam ke-20 dengan nilai TVB 26,58 mg N/100 g, sedangkan hasil minimum yaitu konsentrasi $2,5 \%$ batas ikan layak dikonsumsi pada jam ke-20 dengan nilai TVB 30,61 mg N/100 g. Ikan Lele (Clarias batrachus) dengan perlakuan disemprot hasil maksimun yaitu konsentrasi 1,5\% batas ikan layak dikonsumsi pada jam ke-20 dengan nilai TVB 30,45 mg N/100 g, sedangkan hasil minimum yaitu konsentrasi $2,5 \%$ batas ikan layak dikonsumsi pada jam ke-20 dengan nilai TVB 35,83 mgN/100 g. Sedangkan pada keadaan normal (sebelum pengawetan) ikan mulai membusuk pada jam ke-15 dengan nilai TVB 31,82 $\mathrm{mgN} / 100 \mathrm{~g}$ dan pada jam ke-20 nilai TVB 57,11 $\mathrm{mgN} / 100 \mathrm{~g}$. Dari uraian diatas dapat dilihat bahwa data hasil penelitian dengan perlakuan memiliki nilai TVB yang rendah dibandingkan dengan keadaan normal (sebelum pengawetan). Hal ini dapat disimpulkan bahwa penambahan kitosan 1,5 $\%$ memberikan umur ikan yang lebih lama untuk sampai pada fase ikan busuk dengan nilai TVB > 
30 yaitu dengan menambah umur ikan selama 5-10 jam.

Berdasarkan gambar 2.a nilai TVB semakin meningkat seiring bertambahnya waktu penyimpanan. Hal ini dikarenakan terjadinya aktivitas enzim pengurai yang mulai bekerja [19], Peningkatan jumlah TVB-N disebabkan meningkatnya aktivitas mikroba yang menghasilkan berbagai senyawa yang berbeda, dan sebagian besar diantaranya adalah basa. Nilai TVBN dipengaruhi oleh jumlah non-protein nitrogen yang ada pada ikan, yang semuanya tergantung pada tipe makanan, musim penangkapan dan ukuran ikan [10].

Berdasarkan gambar 2.b nilai TVB semakin meningkat seiring bertambahnya waktu penyimpanan. Hal ini dikarenakan TVB merupakan senyawa hasil degradasi protein karena aktivitas enzim maupun bakteri pembusuk [8], Peningkatan konsentrasi TVB berhubungan dengan pertumbuhan mikroba dan dapat digunakan sebagai indikator kerusakan ikan. Banyaknya jumlah mikroba pada ikan menjadikan proses degradasi protein menjadi senyawa basa nitrogen lebih cepat sehingga konsentrasi TVB juga meningkat tajam [13]. Hasil penelitian konsentrasi kitosan maksimum yang diperoleh adalah $1,5 \%$ sedangkan pada konsentrasi 1\%, 2\% dan 2,5\% ikan lebih cepat membusuk karena lapisan kitosan tidak seluruhnya dapat mengahambat bakteri [8].

Gambar 2.a dan 2.b menunjukkan bahwa nilai TVB dengan perlakuan direndam pada masingmasing ikan memiliki nilai TVB yang lebih rendah dibandingkan dengan nilai TVB pada perlakuan disemprot. Gambar 2.a dan 2.b juga menunjukkan bahwa nilai TVB pada ikan kembung (Rastrelliger sp) lebih rendah daripada nilai TVB ikan lele (Clarias batrachus). Pernyataan ini didukung Erlangga menyatakan bahwa ikan yang tidak bertahan lama tanpa media air (ikan kembung) memiliki nilai TVB yang lebih rendah dibanding dengan ikan yang bertahan lama tanpa media air (ikan lele). Perbedaan nilai TVB ini disebabkan ikan yang bertahan lama tanpa media air diduga memiliki kandungan energi yang sedikit karena mengalami perlawanan sesaat sebelum kematian. Ikan yang lebih banyak mengeluarkan energi sebelum mati akan menyebabkan $\mathrm{pH}$ cepat menurun dan mengaktifkan enzim yang mampu menguraikan protein. Penguraian ini akan meningkatkan basa-basa volatile sehingga nilai TVB meningkat [5].

\section{Analisa pH (Power of Hydrogen)}

Penentuan nilai $\mathrm{pH}$ merupakan salah satu indikator pengukuran tingkat kesegaran ikan. Pembusukan dan perubahan $\mathrm{pH}$ daging ikan disebabkan karena proses autolisis dan penyerangan bakteri [1].
Berikut akan dijelaskan hasil Analisa $\mathrm{pH}$ (Power of Hydrogen) pada ikan kembung (Rastrelliger sp) dan ikan lele (Clarias batrachus) sebagai berikut.

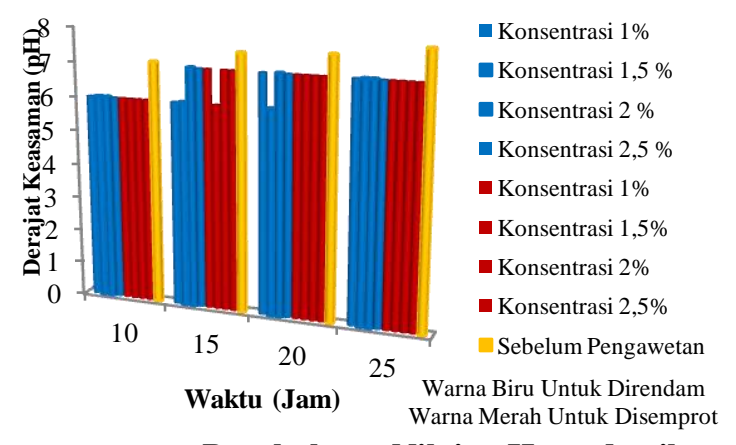

Gambar 3.a Perubahan Nilai pH pada ikan kembung (Rastrelliger sp)

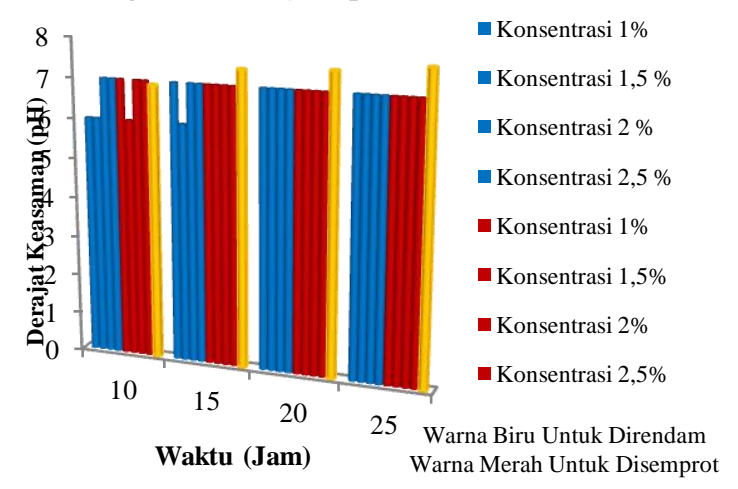

\section{Gambar 3.b Perubahan Nilai pH pada ikan lele} (Clarias batrachus)

Penentuan nilai derajat keasaman $(\mathrm{pH})$ merupakan salah satu indikator pengukuran tingkat kesegaran ikan. Pembusukan dan perubahan $\mathrm{pH}$ daging ikan disebabkan karena proses autolisis dan penyerangan bakteri [16].

Pada gambar 3.a menunjukkan bahwa ikan kembung (Rastrelliger sp) dengan perlakuan direndam hasil maksimum yaitu konsentrasi $1,5 \%$ batas ikan layak dikonsumsi pada jam ke-20 dengan nilai $\mathrm{pH} 6$, sedangkan hasil minimum yaitu konsentrasi 2,5\% batas ikan layak dikonsumsi pada jam ke-10 dengan nilai 6. Ikan kembung (Rastrelliger $s p$ ) dengan perlakuan disemprot hasil maksimum yaitu konsentrasi $1,5 \%$ batas ikan layak dikonsumsi pada jam ke-15 dengan nilai $\mathrm{pH} 6$, sedangkan hasil minimum yaitu konsentrasi 2,5\% batas ikan layak dikonsumsi pada jam ke-10 dengan nilai $\mathrm{pH}$ 6. Sedangkan pada keadaan normal (sebelum pengawetan) ikan sudah mulai tidak segar pada jam ke-10 dengan nilai $\mathrm{pH} 7,1$. Dari uraian diatas dapat dilihat bahwa data hasil penelitian pada keadaan normal (sebelum pengawetan) ikan lebih cepat membusuk daripada hasil penelitian dengan perlakuan.

Pada gambar 3.b menunjukkan bahwa ikan lele (Clarias batrachus) dengan perlakuan direndam hasil maksimum yaitu konsentrasi $1,5 \%$ batas ikan layak dikonsumsi pada jam ke-15 dengan nilai pH 6 , 
sedangkan hasil minimum yaitu konsentrasi 2,5\% batas ikan layak dikonsumsi pada jam ke-10 dengan nilai $\mathrm{pH}$ 6. Ikan lele (Clarias batrachus) dengan perlakuan disemprot hasil maksimum yaitu konsentrasi $1,5 \%$ batas ikan layak dikonsumsi pada jam ke-15 dengan nilai $\mathrm{pH} 6$, sedangkan hasil minimum yaitu konsentrasi $2,5 \%$ batas ikan layak dikonsumsi pada jam ke-10 dengan nilai $\mathrm{pH} 6$. Sedangkan pada keadaan normal (sebelum pengawetan) batas ikan layak dikonsumsi pada jam ke-10 dengan nilai pH 6,9. Dari uraian diatas dapat dilihat bahwa data hasil penelitian pada keadaan normal (sebelum pengawetan) ikan lebih cepat membusuk daripada hasil penelitian dengan perlakuan.

Gambar 3.a dan 3.b menunjukkan bahwa $\mathrm{pH}$ dengan perlakuan direndam pada masing-masing ikan memiliki $\mathrm{pH}$ yang lebih rendah dibandingkan dengan $\mathrm{pH}$ pada perlakuan disemprot. Gambar 3.a dan 3.b juga menunjukkan bahwa $\mathrm{pH}$ pada ikan kembung (Rastrelliger sp) lebih rendah daripada $\mathrm{pH}$ ikan lele (Clarias batrachus). Kecepatan perubahan nilai $\mathrm{pH}$ juga dipengaruhi kondisi ikan sesaat sebelum mati. Kondisi ikan yang stres menjelang kematian akan menyebabkan peningkatan aktivitas otot dibandingkan kondisi ikan yang tidak stress [5].

Peningkatan aktivitas otot akan menyebabkan cadangan glikogen pada daging ikan berkurang [5] akibatnya $\mathrm{pH}$ ikan akan meningkat. $\mathrm{pH}$ dalam daging ikan segar sering antara 6,0 dan 6,5. Pada periode post rigor, dekomposisi senyawa nitrogen menyebabkan peningkatan $\mathrm{pH}$ dalam daging ikan. Peningkatan $\mathrm{pH}$ menunjukkan penurunan kualitas (Shenderyuk and Bykowski, 1990) dalam [12]. Menurut Eskin, tinggi rendahnya $\mathrm{pH}$ awal ikan tergantung pada kandungan glikogen. Glikogen pada tubuh ikan akan diuraikan menjadi asam laktat melalui proses glikolisis, sehingga terjadi penumpukan asam laktat [6].

\section{Analisa Organoleptik}

Berikut akan dijelaskan hasil analisa organoleptik pada ikan kembung (Rastrelliger $s p$ ) dan ikan lele (Clarias batrachus) sebagai berikut.

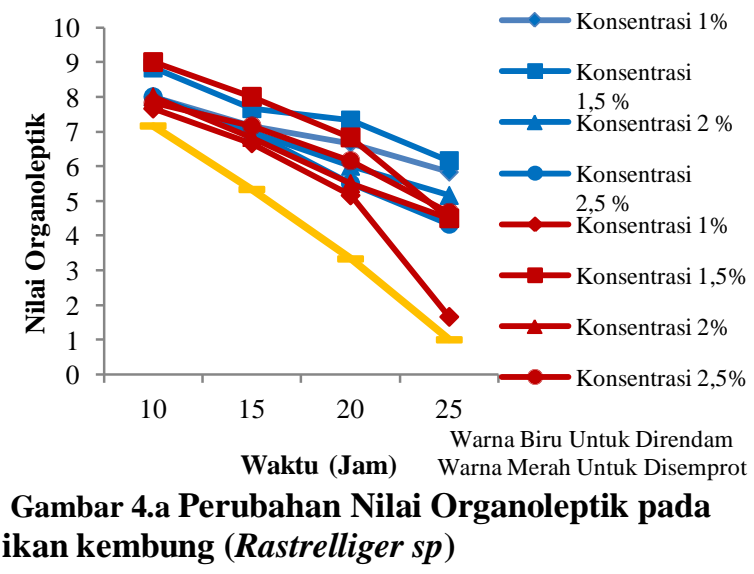

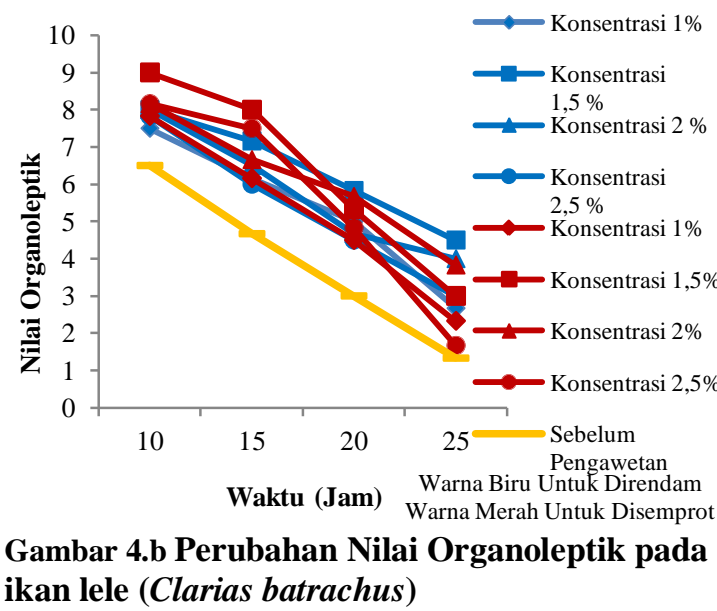

Pada gambar 4.a menunjukkan bahwa ikan kembung (Rastrelliger $s p$ ) pada perlakuan direndam hasil maksimum yaitu konsentrasi $1,5 \%$ batas ikan layak dikonsumsi pada jam ke-20 dengan nilai ratarata 7,33 ; sedangkan hasil minimum yaitu konsentrasi $1 \%$ batas ikan layak dikonsumsi pada jam ke-20 dengan nilai rata-rata 5,5. Ikan kembung (Rastrelliger $s p$ ) dengan perlakuan disemprot hasil maksimum yaitu konsentrasi 1,5\% batas ikan layak dikonsumsi pada jam ke-20 dengan nilai rata-rata 6,83 ; sedangkan hasil minimum yaitu konsentrasi

$1 \%$ batas ikan layak dikonsumsi pada jam ke-20 dengan nilai rata-rata 5,16. Sedangkan pada keadaan normal (sebelum pengawetan) batas ikan layak dikonsumsi pada jam ke-20 dengan nilai ratarata 3,33 .

Pada gambar 4.b menunjukkan bahwa ikan lele (Clarias batrachus) pada perlakuan direndam hasil maksimum yaitu konsentrasi $1,5 \%$ batas ikan layak dikonsumsi pada jam ke-15 dengan nilai rata-rata 7,16; sedangkan hasil minimum yaitu konsentrasi $2,5 \%$ batas ikan layak dikonsumsi pada jam ke-15 dengan nilai rata-rata 6. Ikan lele (Clarias batrachus) dengan perlakuan disemprot hasil maksimum yaitu konsentrasi $1,5 \%$ batas ikan layak dikonsumsi pada jam ke-15 dengan nilai rata-rata 8 , sedangkan hasil minimum yaitu konsentrasi $1 \%$, batas ikan layak dikonsumsi pada jam ke-15 dengan nilai rata-rata 6,16. Sedangkan pada keadaan normal (sebelum pengawetan) batas ikan layak dikonsumsi pada jam ke-15 dengan nilai ratarata 4,67 .

Berdasarkan gambar 4.a dari hasil organoleptik, dapat disimpulkan bahwa semakin lama penyimpanan maka nilai organoleptik semakin menurun. Pada penyimpanan 20 jam dengan perlakuan direndam dan dengan perlakuan disemprot nilai organoleptik sudah mengalami kemunduruan mutu karena nilai organoleptik sudah tidak bisa diterima lagi dan tidak aman untuk dikonsumsi apabila nilai uji sensori berkisar antara 4-1 [5]. Penurunan nilai organoleptik yang tinggi menunjukkan ikan telah mengalami pembusukan 
yang menyebabkan daging ikan menjadi lembut dan lunak. Hal ini disebabkan adanya proses autolisis yang menimbulkan perubahan pada daging, seperti daging menjadi lunak dan mudah lepas dari tulang [11].

Berdasarkan gambar 4.b dari hasil organoleptik, dapat disimpulkan bahwa semakin lama penyimpanan maka nilai organoleptik semakin menurun. Pada penyimpanan 15 jam dengan perlakuan direndam dan dengan perlakuan disemprot nilai organoleptik sudah mengalami kemunduruan mutu karena nilai organoleptik sudah tidak bisa diterima lagi dan tidak aman untuk dikonsumsi. Dapat dilihat dari hasil penelitian terjadi penurunan nilai organoleptik seiring dengan lamanya masa simpan. Hal ini diperkuat oleh Widyasari (dalam Siska Jayanti), bahwa dengan semakin lama masa simpan ikan maka nilai kenampakan akan terus menurun, hal tersebut disebabkan oleh perubahan-perubahan secara fisik, kimiawi dan mikrobiologi [19].

\section{KESIMPULAN}

1. Berdasarkan hasil penelitian kitosan dari cangkang bekicot (Achatina fulica) dapat digunakan sebagai pengawet alami sehingga tidak membahayakan bagi kesehatan serta tidak merusak kualitas produk.

2. Konsentrasi terbaik dari pengawetan ikan dengan cara perendaman dan penyemprotan yaitu penambahan kitosan $1,5 \%$.

3. Pengawetan alami pada ikan kembung (Rastrelliger $s p$ ) dengan menggunakan kitosan dapat memperpanjang umur simpan ikan selama 5 jam.

4. Pengawetan alami pada ikan lele (Clarias batrachus) dengan menggunakan kitosan dapat memperpanjang umur simpan ikan segar selama 10 jam.

5. Berdasarkan analisa $\mathrm{pH}$, organoleptik, dan TVB ikan, cara pemberian larutan dengan cara direndam terbaik sebagai pengawet yang dapat memperpanjang masa ikan segar.

\section{DAFTAR PUSTAKA}

[1] Andien Hapsari, "Pengaruh Perendaman Dengan Larutan Cuka 5\% Dan Air Panas Terhadap Pelepasan Kadar Formalin Pada Cumi-Cumi, Ikan Gembung, Udang Dan Ikan Dencis Secara Spektrofotometri Sinar Tampak", Skripsi, Fakultas Farmasi, Universitas Sumatera Utara, Medan, 2010.

[2] Fibra Nurainy, Samsul Rizal dan Yudianto, "Pengaruh Konsentrasi Kitosan Terhadap Aktivitas Antibakteri dengan Metode Difusi Agar (Sumur)", Jurnal Teknologi Industri dan Hasil Pertanian Vol 13, No.2, Jurusan Teknologi Industri Pertanian, Fakultas Pertanian, Universitas Lampung, 2008.
[3] Dini Nurfianti, "Penggunaan Kitosan Sebagai Pemebentuk Gel dan Pengawet Bakso Ikan Kurisi (Nemipterus nematophorus) pada Penyimpanan Suhu Chilling", Skripsi, Program Studi Teknologi Hasil Perikanan, Fakultas Perikanan dan Ilmu Kelautan, Institut Pertanian Bogor, 2007.

[4] Eko Susanto, Tri W Agustini, Fronthea Swastawati, Titi Surti, Akhmad S. Fahmi, Mahmud F. Albar dan Muhammad K. Nafis, "Pemanfaatan Bahan Alami Untuk Memperpanjang Umur Simpan Ikan Kembung (Rastrelliger Neglectus)", Jurnal Perikanan (J. Fish. Sci.) XIII (2): 60-69 ISSN: 0853-6384, Program Studi Teknologi Hasil Perikanan, Jurusan Perikanan, Fakultas Perikanan dan Ilmu Kelautan, Universitas Diponegoro, 2011.

[5] Erlangga, "Kemunduran Mutu Fillet Ikan Lele Dumbo (Clarias Gariepinus) Pada Penyimpanan Suhu Chilling Dengan Perlakuan Cara Kematian", Skripsi, Program Studi Teknologi Hasil Perikanan, Fakultas Perikanan Dan Ilmu Kelautan, Institut Pertanian Bogor, 2009.

[6] Eskin, "Biochemistry of Food Second Edition", Academic Press, Inc. San Diego, 1990.

[7] Farber L. "Freshness Test", Di dalam Fish As Food, Borgstrom G (Editor), New York: Academic Press, 1965.

[8] Farida Ariyani, Jovita Tri Murtini, Ninoek Indriati, Dwiyitno dan Yusma Yenni, "Penggunaan Glyroxyl untuk Menghambat Penurunan Mutu Ikan Mas (Cyprinus carpio) Segar", Jurnal Perikanan (J. Fish. Sci.) IX (1):125-133 ISSN:0853-6384, Pusat Riset Pengolahan Produk dan Sosial Ekonomi Kelautan dan Perikanan, Badan Riset Kelautan dan Perikanan, Petamburan VI, Jakarta, 2007.

[9] F. Widhi Mahatmanti, Warlan Sugiyo dan Wisnu Sunarto, "Sintesis Kitosan dan Pemanfaatannya Sebagai Anti Mikrobia Ikan Segar", Laporan Pengabdian Kepada Masyarakat, Fakultas Matematika dan Ilmu Pengetahuan Alam, Universitas Negeri Semarang, hal. 101, 2011.

[10] Goulas, A. E, \& M.G. Kontominas, "Combined effect of light salting, modifi ed atmosphere packaging and oregano essential oil on the shelf-life of sea bream (Sparus aurata): Biochemical and sensory attributes", Journal Food Chem. 100, 287-296, 2007.

[11] Gustini, Siti Khotimah dan Ari Hepi Yanti, "Kualitas Ikan Kembung (Rastrelliger kanagurta) Setelah Perendaman dalam Kitosan ditinjau dari Aspek Mikrobiologi dan Organoleptik", Jurnal Protobiont, Vol 3 
(2): 100-105, Program Studi Biologi, Fakultas MIPA, Universitas Tanjungpura, 2014.

[12] Hunkar Avni Duyar and Esra Eke, "Production and Quality Determination of Marinade from Different Fish Species", Journal of Animal and Veterinary Advances, Vol : 8, Issue : 2, Page No : 270- 275, 2009.

[13] Joko Santoso, Fie Ling dan Ratna Handayani, "Pengaruh Pengkomposisian dan Penyimpanan Dingin terhadap Perubahan Karakteristik Surimi Ikan Pari (Trygon $s p$ ) dan Ikan Kembung (Rastrelliger sp)", Jurnal Departemen Teknologi Hasil Perairan, Fakultas Perikanan dan Ilmu Kelautan, IPB, Bogor.

[14] Muhamad Yudanto Tri Atmojo, "Pemanfaatan Lembaran Kitosan Sebagai Adsorber Pada Pengolahan Limbah Cair Perikanan", Skripsi, Program Studi Teknologi Hasil Perikanan, Fakultas Perikanan dan Ilmu Kelautan, Institut Pertanian Bogor, Bogor, hal 7, 2007.

[15] No H.K, N.Y. Park, S.H. Lee, and S.P. Meyer, "Antibacterial activity of chitosans and chitosan oligomers with different molecular weight", International J. of Food Microbiol, 74: 65-72, 2002.

[16] Rita Kaparang, Silvana D dan Ketut Sutweja, "Penentuan Mutu Ikan Tandipang (Dussumieria Acuta C.V) Asap Kering Selama Penyimpanan Suhu Kamar”, Jurnal, Teknologi Hasil Perikanan, FPIK, UNSRAT, 2011.

[17] Robert Domsay TM, "Evaluation of Infra Red Spectroscopic Techniques for analyzing Chitosan”. Journal Macromol Chem. 186:1671, 1985.

[18] Rosa Dewi Pratiwi, Ari Eka Suryaningsih, Siska Ela Kartika, Fauzi Alhidayat dan Heri
Widodo, "Pelatihan Pembuatan Chitosan Dari Limbah Udang Sebagai Bahan Pengawet Alami Untuk Memperlama Daya Simpan Pada Makanan di Kelurahan Pucangsawit", Proposal PKMM Dikti, Universitas Sebelas Maret, Surakarta, 2008.

[19] Siska Jayanti, Mirna Ilza dan Desmelati, "Pengaruh Penggunaan Minuman Berkarbonasi Untuk Menghambat Kemunduran Mutu Ikan Gurami (Osphronemus Gouramy) Pada Suhu Kamar”, Fakultas Perikanan dan Ilmu Kelautan Universitas Riau, Jurnal Perikanan dan Kelautan 17,2: 71:87, 2012.

[20] Srijanto, B, "Kajian Pengembangan Teknologi Proses Produksi Kitin dan Kitosan Secara Kimiawi", Prosiding seminar Nasional Teknik Kimia Indonesia, Volume I, hal F01-1 - F01-5, 2003.

[21] Suptijah P.E, Salamah E, Sumaryanto H, Purwaningsih S, Santoso J, "Pengaruh Berbagai Metode Isolasi Kitin Kulit Udang Terhadap Mutunya", Laporan Penelitian, Jurusan Pengolahan Hasil Perikanan, Fakultas Perikanan, IPB, Bogor 1992.

[22] Triana Kusumaningsih, Abu Masykur dan Usman Arief, "Pembuatan Kitosan dari Kitin Cangkang Bekicot (Achatina fulica)", Jurnal Biofarmasi, 2(2), 64-68, Agustus 2004, ISSN: 1693-2242, Jurusan Biologi, FMIPA UNS, Surakarta.

[23] Zheng, Lian Ying dan Zhu, Jiang Feng, "Study on Antimicrobial Activity of Chitosan With Different Molecular Weights", Journal Carbohydrate Polimers, 54(4), 527-530. Department of Chemical and Biochemical Engineering, Zhejiang University, China, 2003. 